\title{
THE IMPORTANCE OF ENTEROCOCCUS BACTERIA IN ETHIOLOGY OF URINARY TRACT INFECTION
}

\author{
Gordana Smieško \\ University of Novi Sad, Medical Faculty, \\ Institute of Public Health of Vojvodina, Novi Sad, Serbia
}

Primljen/Received 02. 02. 2019. god.

Abstract: Enterococci are classified as Streptococcus D group. Genetic studies in the 1980s have led to the conclusion that they have enough distinction to be classified into a particular genus.

Enterococci cause: urinary infections, especially in patients with catheter, in immunocompromised individuals, the infections of the biliary tract, soft tissue abscess, and wound infection. It is a relatively common cause of endocarditis, especially in people with damaged or artificial heart valve. Enterococci are the most common cause of urinary tract infections (IUT): about $10 \%$ of all and about $16 \%$ of intra-hospital IUT. In second place in frequency are intra-abdominal and pancreatic wounds, but these infections often cause multiple causes, so the assessment of the importance of enterococci in them is debatable. In third place is the bacteremia most commonly occurring in hospital conditions in immunocompromised patients who are lying long in hospitals and receiving antibiotics.

Key words: Enterococci, urinary tract, infection.

\section{INTRODUCTION}

Enterococcus bacteria represent a part of the normal microflora of the intestinal, biliary and female genital tract. They are natural components of soil, water, raw plants and animal products, where they increase the aromaticity (cheese and sausages). They are used as probiotics to improve the microbiological balance of the intestinal tract of both animals and humans.

In recent years, Enterococcus spp has become one of the leading causes of intra-hospital (nosocomial) infections in the urinary tract. What is an additional problem is increased resistance to antimicrobial drugs $(1,2,3)$.

Enteroccuc species are gram positive cocci. The species consist more than 17 species, of which only a few cause disease in humans. More than $90 \%$ of human
Prihvaćen/Accepted 16. 04. 2019. god.

isolates are: Enteroccocus fecalis and Enterococcus feacium. Others that cause infection in humans are E.avium, E.gallinarum, E.Durans, E.raffinosis (Figure 1. and Figure 2).

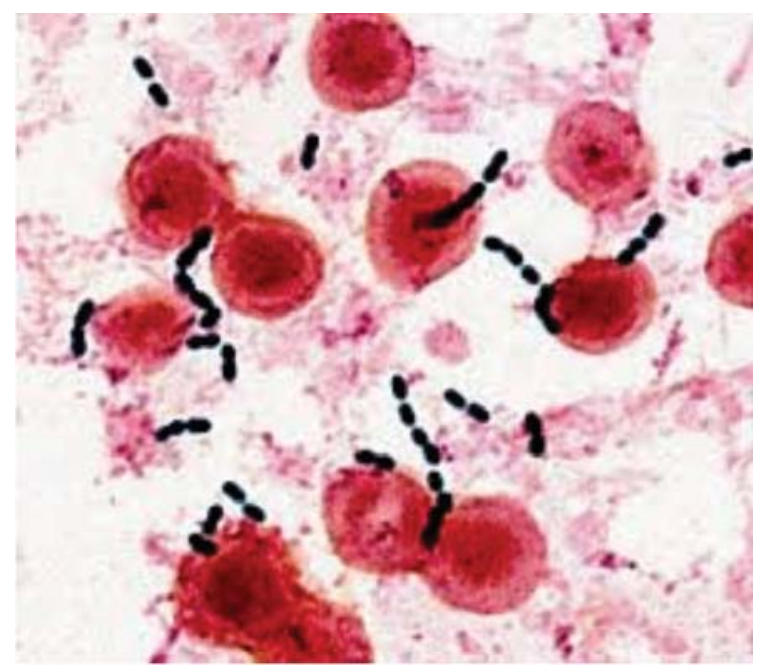

Figure 1. Microscopic view of enterococci

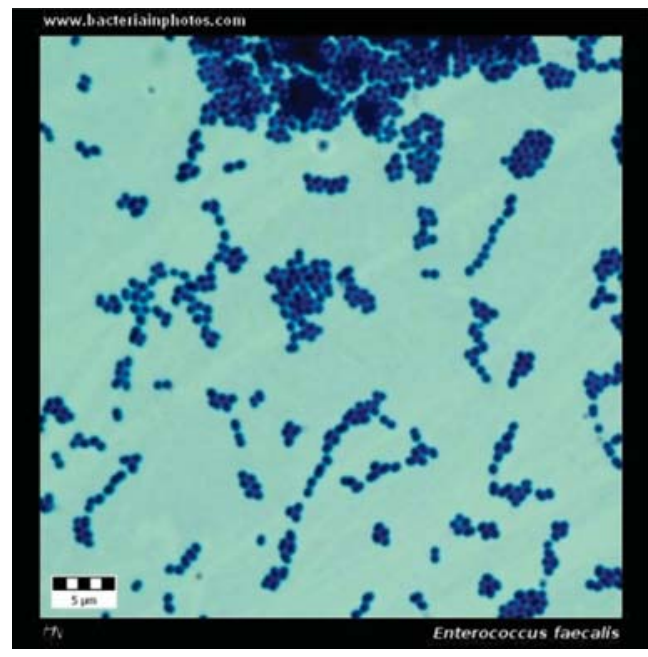

Figure 2. Microscopic view of enterococci 
Initially, Enterococci are classified as Streptococcus D group. Genetic studies in the 1980s have led to the conclusion that they have enough distinction to be classified into a particular genus.

Enterococci cause: Urinary infections, especially in patients with catheter. In immunocompromised individuals, the infections of the biliary tract, soft tissue abscess, and wound infection. It is a relatively common cause of endocarditis, especially in people with damaged or artificial heart valve. Enterococci are the most common cause of urinary tract infections (IUT): about $10 \%$ of all and about $16 \%$ of intra-hospital IUT. In second place in frequency are intra-abdominal and pancreatic wounds, but these infections often cause multiple causes, so the assessment of the importance of enterococci in them is debatable. In third place is the bacteremia most commonly occurring in hospital conditions in immunocompromised patients who are lying long in hospitals and receiving antibiotics.

\section{Pathogenicity of Enteroccocus}

A model of the urinary tract of the mouse was used to study pathogenesis of $\mathrm{E}$. faecalis in the urinary tract. It has been shown that $\mathrm{E}$. faecalis has an advantage in developing compared to other bacteria from the genus of the renal kidney transmitted through blood by inoculation of pyelonephritis. They used another model to demonstrate that pyelonephritis, which causes Pseudomonas aeruginosa, is worser by E. fecalis, causing histological changes in the kidneys. The preoccupation of E. faecalis to kidneys in relation to the epithelium of the bladder is one of the possible explanations, but host factors involved in innate defense can also play an important role $(4,5,6)$.

Urinary tract infections (IUT) whose E. faecalis mediator occur according to a strictly different mechanism from IUT mediated E. coli. In the typical case of IUT via E. coli, bacteria attack the surface umbilical cells and repeat it to higher levels, forming intracellular biofilms. The process is caused by a cytokine, a mediator of TLR4, which groups neutrophils to the site of infection.

In Enterococcus infections there is little or no inflammation in the fetus. Neutrophils represent only a small portion of the inflammatory cells at the site of the infections in the kidney. TLR2, which plays a role in the congenital response to gram positives, such as TLR4 plays a role in gram-negative, does not play a significant role in the congenital reaction to E.faecalis in the urinary tract. The recent discovery of the TLR11 receptor, which specifically recognizes uropathogens, indicates an additional innate mechanism that the host uses to respond to the enterococcus.
The ability of Enterococci to cause kidney disease is precisely established. The diagnosis of infection of the upper tract, or the lower, which causes Enterococcus, as well as gram-negative bacilli, is generally based on signs and symptoms. Therefore, the presence of fever and pain in slabs, with or without symptoms in the lower parts of the urinary tract, such as dysuria, frequency and urgency, indicate an infection of the upper part of the urinary tract. It is considered that symptoms in the lower part of the tract without symptoms in the upper part tracts represent infection of the bladder. Since Enterococcus has a strong kidney tropism, most of the episodic cystitis episodes are due to the transmission of infection from the upper urinary tract. Also, asymptomatic bacteriuria with Enterococcus is more often localized in the upper part than in the bladder. And as Enterococcal infections of the urinary tract bind to upper tract infections, it is possible to perform the implications of treatment. As infection of the upper urinary tract of the lens is longer than bladder infections $(7,8,9)$.

Enterococcal infection occurs more frequently until the age of 10 and after the 60's, when genitourinary anomalies and obstructive abnormalities are more frequent. Enterococci are the third most common uropathogen-acquired urinary tract infection after E.coli and P.aeruuginosa. Over $50 \%$ is in patients on stationary treatment, where there is a catheter. Also, neurological patients are targeted because of their specific condition when catheter is used.

These infections are not rare, but their diagnosis is not easy to establish. As it is usually associated with obstructive uropathy caused by urological and/or neurological disorders, their clinical manifestations may be mild or even absent. Pyuria is common, but it is non-specific manifestation in the absence of symptoms. It can be overwritten by catheterization and / or due to the presence of instruments in neurological symptoms or obstructive uropathy. In addition, the diagnosis of urinary tract infection caused by Enteroccocus spp may indicate anomalies in the urinary tract that will only be diagnosed.

Enterococci have more genes that encode the factors responsible for the transmission of virulence.

Asa 1-plasmid gene. Codes the synthesis of the aggregation substance (AS). It is a protein that mediates binder binding to the host epithelium. It also mediates the plasmid exchange of information during bacterial conjugation.

Efa A-gene responsible for "avoiding" the immune response. It encodes the creation of a enterococcus surface protein (ESP), which participates in colonization, sustainability and the formation of biofilm on the surface of the urinary tract. 
Esp-part of the great "pathogenic island", where other pathogenic genes are located.

Responsible for endocarditis and urinary infections and the creation of biofilm on cell epithelium by E.faecium.

ACE-encodes a protein mediating the adhesion of bacteria to collagen host cells.

HYL A-encodes hyaluronidase that plays an important role in the increase of bacterial invasion, especially the intestinal tract. The only isolated out-of-hospital community did not have a large plasmid containing this gene. The strains isolated from hospital patients are.

CYL A- gene for coding cytolysis of both eukaryotic and prokaryotic cells.

GEL E-gen responsible for synthesis of Zn metalloendopeptidase, which hydrolyzes gelatin, casein and hemoglobin.

IS16- encodes the enzymes necessary for bacterial transposition.

One of the main problems associated with the genus Enterococci is the tendency to gain resistance and the spread of antimicrobial determinants of resistance.

\section{Hospital infections and Enteroccocus}

Enterococci represent $16 \%$ of the causes of all nasocomial infections. Studies show that the urinary tract is the most common source of hospital infections. The main causes of this genus are E.faecium and E.faecalis. Enterococcus faecium has always had a higher degree of drug resistance, than $\mathrm{E}$.faecalis.

But what's characteristic of the one-line is a high degree of resistance, such as the ability to survive under unfavorable conditions (temperature from 10 to 46 , $\mathrm{ph}=9.6$ ), high resistance to antibiotics, etc.

Including non-selective use of antibiotics, prolonged hospitalization, seriousness of the disease and impaired immune response (already hospitalized patients), all of these factors are responsible for making Enterococci resistant to medication during hospital treatment. This eventually leads to environmental pollution and other infections.

\section{Catheterization}

It has been established that the presence of catheter plays a major role. It is necessary to pay attention to the duration of catheterization (preferably up to 30 days, no more) and that the catheter is always open.

The drainage bag should always be below the level of the bladder and tube.

In case of short-term catheterization, systemic antibiotics prophylaxis is not recommended. Also for patients who use catheterization with interruptions, pro- phylaxis by antibiotics is not effective. Cleaning the catheter with anibiotics and antiseptics is no progress. But catheters are introduced under antiseptic conditions. Medical staff respects the hygienic conditions in accordance with the protocol. Patients my for more than 10 years use catheters should be checked regularly for possible bladder cancer. Antibiotic therapy has proven effective only in cases of symptomatic infection. Treatment with antibiotics begins after the results of the urinary culture. Evacuate catheter before surgery. The silver and aluminum catheters have proven to be effective, i.e., causing asymptomatic bacteria, but only if used for up to 7 days. Preventing urinary infections caused by catheter or at least mitigating them is still a form of research.

In case of short-term catheterization, systemic antibiotics prophylaxis is not recommended. Also for patients who use catheterization with interruptions, prophylaxis by antibiotics is not effective. Cleaning the catheter with anibiotics and antiseptics is no progress. But catheters are introduced under antiseptic conditions. Medical staff respects the hygienic conditions in accordance with the protocol. Patients my for more than 10 years use catheters should be checked regularly for possible bladder cancer. Antibiotic therapy has proven effective only in cases of symptomatic infection. Treatment with antibiotics begins after the results of the urinary culture. Evacuate catheter before surgery. The silver and aluminum catheters have proven to be effective, i.e., causing asymptomatic bacteria, but only if used for up to 7 days. Preventing urinary infections caused by catheter or at least mitigating them is still a form of research.

It should be noted that the resistance gene placed on plasmids can be easily and rapidly expanded horizontally, while the genes located on the chromosome are, as a rule, wider vertically and horizontally if it is a transposon that passes from the chromosome to a plasmid, and further propagates with a plasmid or a mechanism of transformation which in nature is probably not common (the transfer of a large part of the chromosomal DNA into a related bacterium).

\section{Resistance to antibiotics}

Resistance to antibiotics makes them ungrateful for treatment. There are two types of resistance:

\section{Internal resistance}

Characteristic of the species mediated by genomes located on chromosomes and is present in all members of the species. Enterococci show internal resistance to:beta lactams, cephalosporins, lincosamide, classical quinolones, aminoglycosides-show low levels of resistance, clindamycin. 
Although most enterotoxic agents are sensitive to co-trimoxazole in vitro, this combination does not work when administered in vivo, as the Enterococcus is able to "skip" folic acid and bypass the inhibition of folate synthesis by co-trimoxazole. For his DNA, Enterococcus use exogenous folic acid.

\section{Acquired resistance}

Stems from mutations at DNA level DNA examples of acquired resistance:, ampicillin, HLAR-aminoglycosides, vancomycin, chloramphenicol, erythromycin, high levels of clindamycin, tetracyclon, fluoroquinolone.

The unpredictable sensitivity of Enterococcus to antibiotics requires testing of sensitivity, or resistance in vitro. When and on which antibiotics will the sensitivity of Enterococci be, depends on the site of infection and the estimated significance of a particular isolate.

Acquired resistance was found on all antibiotics that affect the enterotox (10-13). But they were also found on those antibiotics that are not used to treat enterococcal infection. The reason for this is the transfer of the resistance gene horizontally-to other types of bacteria, which are treated with other antibiotics, to which they now become resistant.

\section{VRE (vancomicyn resistance Enterococci) \\ Colonization and infection}

It is believed that a faecal transfer of VRE is often associated with a serious clinical infection and that it is very likely that colonization of the gastrointestinal tract occurs as a prelude to a clinical infection.

Risk factors for colonization and invasive diseases include the use of antibiotics (especially vancomycin, the third generation cephalosporins and antimicrobial agents against anaerobic activity, etc.) and various other factors, including the pre-mentioned colonization of the gastrointestinal tract (GI) with the VRE, the prolonged stay in the hospital, older age, proximity to the patient, care for patients with colonization of the gastrointestinal tract with VRE by the healthcare worker (14-18).

Furthermore, these colonized patients can contaminate themselves and the environment, and therefore have the potential to transfer VRE from the environment to patients. How VRE can survive on dry surfaces for a long time, it contaminates the environment by causing some diseases.

\section{Screening method for determining VRE}

Given the increasing rate of colonization with VRE and the increased concern over the possible impact of this organism on patients at high risk of infec- tion, screening methods for the determination of VRE have been introduced. A reliable and recommended method of agar screening method involves the use of BHI (brain-heart infusion) agar with 6 ig vancomycin per $\mathrm{ml}$. The detected plates of inoculum 105-106 cfu (colony forming unit), were incubated at $35 \mathrm{E} \mathrm{C}$ for 24 hours. Their growth shows resistance, and absence of growth shows sensitivity.

Two enterotoxal solutions for the isolation of VRE from colonized patients are also available. These are enterotoxic mixtures with sodium azithromycin with sodium azide with 6 ig vancomycin (EBVA) and M-enterotoxic mixture with sodium azide and trifenyltetrazolium with 6 ig vancomycin.

Similarly, the antibiotic gradient (E test) method can also detect VRE. When suspicion of the results of the screening method is suspected, vancomycin should be confirmed using another method.

\section{Daptomycin}

Daptomocin is a cyclic lipopeptide antibiotic with a rapid bactericidal effect per gram of positive. It works by binding to the cell membrane, performing depolarization, inhibiting protein synthesis, DNA, RNA, and leading to cell death.

It is eliminated through the kidneys, and more than $50 \%$ in the unchanged state gets into the urine after iv. The above mentioned drugs have a lower percentage of renal excretion, which limits the effectiveness of VRE. Then, its MICs are similar for E.faecium and E.feacalis.

Respiratory response to daptomycin rarely occurs. According to previous studies, the VRE shows a high level of sensitivity to daptomocin. For linezolid, resistance is increasing. Quinopristin has a limited activity on E.faecalis. In addition, adverse effects (myalgia and athralgia) and the rapid increase in resistance have surpassed the benefit. Then, daptomycin has a wide therapeutic index.

A study conducted from January 2007 to December 2009 included hospitalized patients who have VRE and therefore need to stay longer in the hospital with a Foli catheter and this is not the first IUT. All treated patients achieved eradication with daptomycin. It was used in doses of 1.4 to $3.7 \mathrm{mg} / \mathrm{kg}$ per day. The determined doses were based on empirical knowledge of the practice, since there was no accurate dose in literature. An unusually high dose was given to a 30-year-old patient with quadriplegia who had I ST.aureus: $13 \mathrm{mg}$ per $\mathrm{kg}$. Daptomycin eradicated VRE regardless of the new kidney function. Daptomycin was well tolerated and there were no reports of kidney alteration, muscular weakness or pain, nor an increase in CPK enzymes. 
The CPK level was measured at the start of the study and once every 7 to 10 days. Even with the patient who received the highest dose.

This is important for some subsequent studies that would determine the exact dose of daptomycin. The possible expected side effects are: degenerative changes in muscles, rhabdomyolysis and myopathy-the use of daptomycin only once a day reduces myotoxicity. More frequent is the occurrence of myotoxicity in patients with renal insufficiency, and therefore, a new CPC is monitored. If there is an increase, the therapy will be discontinued:gastrointestinal complaints, weakness, headache, screw.

Most VREs can be treated, except vancomycin antibiotics. Laboratory testing allows physicians to determine which antibiotic will work.

VRE is transmitted as well as Enterococcus. In healthy people it will not cause infection. VRE is transmitted by touch of the hand on your hands, when you touch an infected person or after contact with contaminated surfaces or equipment.

VRE infection can be without symptoms. Such people are called colonized and they most often do not even know that they are transmitters. VRE can be diagnosed with IUT, infections in the bloodstream or wounds associated with a catheter or surgical procedure.

We prevent the spread of VRE in hospitals by:

- The staff wash their hands with soap and water or rub their hands with alcohol before and after the care of each patient.

- In some cases, in the case of health services, clothing and gloves may be used to prevent the spread of doctors should take special measures (isolation measures) to prevent the spread of infection to others.

\section{Isolation}

Precautions serve patients with infected or colonized VRE. If a patient has a previous history of VRE isolation in clinical patterns from any source, the patient is sent to precautionary measures, and the Infection Control Department is informed of this. The infection control unit will monitor the patient during his stay in the hospital. Patients who carry vancomycin resistant E. gallinarum strains, E. casseli flavus, or E. flavescens can only be treated with standard precautions. Precautions require a private room and wearing clothing and gloves if it touches the patient or anything in the patient's room by hand or part of the clothing that is contaminated; since Enterococcus is an extremely durable organism and can survive for a longer period of time on objects, and because it spreads on surfaces in hospital rooms (especially in patients with incontinence of the chair), it is considered that all areas in the patient's room are contaminated.

Patients, who are in precautionary measures for isolation, are asked to stay in their rooms as much as possible. Patients may leave the department for treatment and / or therapy, if they observe isolation precautions. When the patient leaves the department, the secretary of the department should call the department to which the patient has started and to inform them of the patient coming from the isolation. Ideally, procedures and theraphies should be performed at the end of the day, away from other patients. When the patient leaves the room he / she should wear a protective suit and wash basins with soap and water. Staff in charge of transporting isolated patients should pay attention to avoid contaminating common areas in the hospital during transportation. The carrier should wear protective clothing and gloves. The carrier's gloves and gloves are considered contaminated and should not have any contact with anything except the patient and/or vehicle.

Conflict of Interest: The authors declare that they have no conflict of interest.

\section{Source of support: None}

Acknowledgement: This research did not receive any specific grant from funding agencies or non-profit sectors.

\section{Licensing}

This work is licensed under a Creative Commons Attribution 4.0 International (CC BY 4.0) License.

\title{
Sažetak
}

\section{VAŽNOST ENTEROKOKA U ETIOLOGIJI URINARNIH INFEKCIJA}

\author{
Gordana Smieško \\ University of Novi Sad, Medical Faculty, \\ Institute of Public Health of Vojvodina, Novi Sad, Serbia
}

Enterokoke su klasifikovane kao Streptokok D grupe. Genetske studije 1980tih su došle do zaključka da se dovoljno razlikuju i da mogu da budu svrstane u posebnu grupu.
Enteroke izazivaju: urinarne infekcije, posebno kod pacijenata koji nose urinarni kateter i kod imunokompromitovanih pacijenata, infekcije bilijarnog trakta, abscese mekih tkiva i infekcije rana. Relativno če- 
sto su uzrok endokarditisa, naročito kod osoba sa oštećenom i arteficijalnom srčanom valvulom. Enterokoke su najčešći uzročnici urinarnih infekcija: oko $10 \%$ od ukupnog broja i oko 16\% intrahospitalnih infekcija urinarnog trakta. Na drugom mestu po učestalosti su intraabdominalne i infekcije pankreasa, ali pošto ove infekcije obično izaziva veći broj uzročnika, onda je

\section{REFERENCES}

1. Hooton TM, Scholes D, Hughes JP, Winter C, Roberts $\mathrm{PL}$, Stapleton AE et al. A prospective study of risk factors for symptomatic urinary tract infection in young women. N Engl J Med. 1996; 335(7): 468-74

2. Hooton TM, Scholes D, Stapleton AE, Roberts PL, Winter C, Gupta K et al. A prospective study of asymptomatic bacteriuria in sexually active young women. N Engl J Med. 2000; 343(14): 992-7.

3. Foxman B, Geiger AM, Palin K, Gillespie B, Koopman JS. First time urinary tract infection and sexual behavior. Epidemiology. 1995; 6(2): 162-8.

4. Delzell JE Jr, Lefevre ML. Urinary tract infections during pregnancy. Am Fam Physician. 2000; 61(3): 713-21.

5. Le J, Briggs GG, McKeown A, Bustillo G. Urinary tract infections during pregnancy. Ann Pharmacother. 2004; 38(10): 1692-701.

6. Sharami SH, Afrakhteh M, Shakiba M. Urinary tract infections in pregnant women with bacterial vaginosis. J Obstet Gynaecol. 2007; 27(3): 252-4.

7. Harmanli $\mathrm{OH}$, Cheng GY, Nyirjesy P, Chatwani A, Gaughan JP. Urinary tract infections in women with bacterial vaginosis. Obstet Gynecol. 2000; 95(5): 710-2.

8. Conde-Agudelo A, Villar J, Lindheimer M. Maternal infection and risk of preeclampsia: systematic review and metaanalysis. Am J Obstet Gynecol. 2008; 198(1): 7-22.

9. Herraiz MA, Hernandez A, Asenjo E, Herraiz I. Urinary tract infection in pregnancy. Enferm Infecc Microbiol Clin. 2005; 23 (suppl 1): 40-6. [Article in Spanish]

10. Jackson SL, Boyko EJ, Scholes D, Abraham L, Gupta K, Fihn SD. Predictors of urinary tract infection after menopause: a prospective study. Am J Med. 2004; 117(12): 903-11. važnost učešća enterokoka u njima diskutabilna. Na trećem mestu je bakterijemija koja se najčešće pojavljuje u bolničkim uslovima kod imunokomromitovanih pacijenata , koji su dugo hospitalizovani i dobijaju antibiotike.

Ključne reči: Enterokoke, urinarni trakt, infekcija.

11. Boyko EJ, Fihn SD, Scholes D, Chen CL, Normand $\mathrm{EH}$, Yarbro P. Diabetes and the risk of acute urinary tract infection among postmenopausal women. Diabetes Care. 2002; 25(10): 1778-83

12. Boyko EJ, Fihn SD, Scholes D, Abraham L, Monsey B. Risk of urinary tract infection and asymptomatic bacteriuria among diabetic and nondiabetic postmenopausal women. Am J Epidemiol. 2005; 161(6): 557-64.

13. Brown JS, Vittinghoff E, Kanaya AM, Agarwal SK, Hulley S, Foxman B, et al. Urinary tract infections in postmenopausal women: effect of hormone therapy and risk factors. Obstet Gynecol. 2001; 98(6): 1045-52.

14. Wellens A, Garofalo C, Nguyen H, Van Gerven N, Sl ttegDrdR, Hernalsteens JP et al. Intervening with urinary tract infections using anti-adhesives based on the crystal structure of the FimHoligomannose- 3 complex. PLoS ONE. 2008; 3(4): e2040.

15. Stothers L. A randomized trial to evaluate effectiveness and cost effectiveness of naturopathic cranberry products as prophylaxis against urinary tract infection in women. Can J Urol. 2002; 9(3): 1558-62.

16. Haverkorn MJ, Mandigers J. Reduction in bacteriuria and pyuria using cranberry juice. JAMA. 1994; 272(8): 590

17. Avorn J, Monane M, Gurwitz JH, Glynn RJ, Choodnovskiy I, Lipsitz LA. Reduction of bacteriuria and pyuria after ingestion of cranberry juice. JAMA. 1994; 271(10): 751-4.

18. McMurdo ME, Bissett LY, Price RJ, Phillips G, Crombie IK. Does ingestion of cranberry juice reduce symptomatic urinary tract infections in older people in hospital? A double-blind, placebo-controlled trial. Age Ageing. 2005; 34(3): 256-61.

\section{Correspondence to/Autor za korespondenciju:}

Gordana Smieško

Department of Microbiology, Faculty of Medicine University of Novi Sad

Hajduk Veljkova 1-7, 21000 Novi Sad, Serbia

Institute of Public Health, Futoška 121, 21000 Novi Sad, Serbia

e-mail: gordana.bojic@mf.uns.ac.rs

Phone: +381 (0) 605115771 